\section{$\underset{\substack{\text { hommes } \\ \text { \& migrations }}}{ }$}

\section{Hommes \& migrations}

Revue française de référence sur les dynamiques

migratoires

\section{$1284 \mid 2010$}

Migrations et environnement

\title{
Eastern plays
}

Film bulgare de Kamen Kalev

\section{André Videau}

\section{(2) OpenEdition \\ 1 Journals}

Édition électronique

URL : http://journals.openedition.org/hommesmigrations/1276

DOI : 10.4000/hommesmigrations. 1276

ISSN : 2262-3353

Éditeur

Musée national de l'histoire de l'immigration

Édition imprimée

Date de publication : 1 mars 2010

Pagination : 200

ISSN : 1142-852X

\section{Référence électronique}

André Videau, « Eastern plays », Hommes \& migrations [En ligne], 1284 | 2010, mis en ligne le 29 mai

2013, consulté le 22 septembre 2020. URL : http://journals.openedition.org/hommesmigrations/1276

; DOI : https://doi.org/10.4000/hommesmigrations.1276

Ce document a été généré automatiquement le 22 septembre 2020.

Tous droits réservés 


\section{Eastern plays}

Film bulgare de Kamen Kalev

\section{André Videau}

Sélectionné à Cannes en 2009 pour la Quinzaine des Réalisateurs, Eastern plays est le premier long-métrage de Kamen Kalev. Repéré par la Fémis après quelques courtsmétrages, ce jeune réalisateur, né à Sofia, a réussi à affirmer son talent dès sa première œuvre, grâce à son acharnement en milieu hostile qu'il a appelé "sa logique de guérilla". Le contexte n'est pourtant pas réjouissant. L'auteur nous entraîne dans la grisaille, voire la noirceur, d'une banlieue postcommuniste. C'est la mobilité de la caméra à l'épaule, l'amertume des sentiments et la verdeur des dialogues qui confèrent au film une certaine vivacité.

Deux copains, perdus de vue depuis les euphories étudiantes, se retrouvent au hasard de quelques verres de bière (de la suédoise, pas de la bulgare!) dans un de ces troquets qui semble avoir le monopole de la distraction et des rares moments favorables aux épanchements et à l'introspection.

4 Avant que le film ne prenne une autre direction en se laissant entraîner par les (faux) pas du frère cadet Georghi, ado déboussolé, embrigadé chez les néonazis (Ovanes Torosian), on va s'attacher surtout à Itso, frère aîné et double de l'auteur (Christo Christov, dont ce sera la première et la dernière apparition à l'écran car il est mort à la fin du tournage, le film lui est dédié). Il est passé sinistrement de l'art à l'artisanat et de tous les possibles de l'École des Beaux-Arts aux horaires bornés d'un atelier de menuiserie. La promesse d'aller faire fortune à l'étranger n'est plus qu'un serment d'ivrogne ou de toxico sous méthadone.

5 Mais la vie a plus d'un tour dans son sac. Lors d'une virée nocturne, Itso assiste à un tabassage raciste. Une famille de touristes turcs est agressée par une bande de nervis. Itso reconnaît Georghi parmi les agresseurs. Le père de famille très amoché est transporté à l'hôpital. Itso lui rend visite, moins pour alléger sa culpabilité que pour les beaux yeux de la fille ottomane. À son tour la victime proférera des paroles insultantes. Les mahométans n'aiment pas les chrétiens et vice versa. Les familles n'ont qu'à se le 
tenir pour dit, rester à leur place et serrer les rangs. Triste constat des vertus du repli identitaire. La leçon fait plus froid dans le dos que chaud au cœur. 